\title{
Reaching Excellence: Staff Weapon Typologies, Contexts, and Fighting Techniques in the Collectanea of Pietro Monte
}

\author{
Jacob Henry Deacon \\ Institute for Medieval Studies, University of Leeds
}

Iason-Eleftherios Tzouriadis

The Worshipful Company of Gold and Silver Wyre Drawers

\begin{abstract}
The sixteenth-century Collectanea of the condottiero Pietro Monte contains some of the most thorough writings that exist pertaining to the use of staff weapons. A detailed study of how these weapons are categorised, contextualised, and used in Monte's work can, due to their sometimes limited treatment in other fight books, allow for a comparative approach between Monte's works and those of other fight book authors. Such a study allows for a more complete understanding of how Monte's work fits in with the wider fight book genre, properly contextualising the Collectanea, and demonstrating to what extent this important but often overlooked text should be considered revolutionary or reflective of contemporary military and martial trends. In this article is discussed Monte's approach to defining staff weapons, his contextualisation of staff weapons according to military and martial environments, and Monte's teachings on the use of staff weapons.
\end{abstract}

Keywords - Pietro Monte, staff weapons, fight books, fighting system, martial arts, Historical European Martial Arts Studies, arms and armour, warfare.

\section{INTRODUCTION}

More so than any other fight book of the period, Pietro Monte's 1509 Exercitorum atque artis militaris collectanea can be said to outgrow its own genre and be considered a nearlyacademic study of fighting and martial thought. Such will be demonstrated throughout this article via an analysis of the staff weapon material in Monte's work, using the limited representation of staff weapons in the wider, heterogenous fight book genre to serve as a microcosm, in turn allowing for Monte's approach to arms and their use to be compared with that of other fight book authors. A comparison of themes present in Monte's treatment of staff weapons to those found in earlier and later fight books will also permit his work to be properly contextualised within the genre, and furthermore question whether his work should be perceived as revolutionary or reflective of contemporary trends in the fight book genre. Given the military relevance of staff weapons, and their centrality to armed combat in Monte's work, this article also acts as an opportunity to discuss the extent to which Monte can be regarded as reflecting contemporary military 
realities in his writings, as opposed to the more commercially driven texts of other fight book authors who usually communicate their subject matter through the lens of different forms of single combat. ${ }^{1}$

The centrality of terminology in this paper is important enough that Monte's works have been quoted substantially. It has often been said that Monte's Latin can be difficult to work with and with this in mind our quotations in the footnotes include both the Latin from 1509 and the 2018 translation of this into English by Jeffrey L. Forgeng. References to the original and translation are distinguished via "Exercitorum" and "Collectanea" respectively after the first instance: the Exercitorum is cited first in footnotes. The version of the Exercitorum consulted by the authors is unpaginated: our foliation begins from the title page.

\section{THE PROBLEM OF CONTEMPORARY AND MODERN STAFF WEAPON DEFINITIONS AND TYPOLOGIES}

In order to fully develop some of the ideas in this article it will be necessary to provide a definition of what constitutes a staff weapon. One of the recurring problems in this field of study is the rarely justified inconsistent terminology and boundaries for weapon groups. $^{2}$ Staff weapons have been defined by Iason-Eleftherios Tzouriadis as two-handed weapons used on foot, which, depending on their type can have different offensive uses including thrusting, cutting, pulling, throwing, and bludgeoning. They can be edged or blunt. Staff weapons mainly consist of two parts: a long wooden shaft surmounted by a metal head. Additional parts are sometimes added to the shaft as part of the finishing

We would like to express our gratitude to Drs Alan V. Murray and Karen Watts for their feedback and suggestions concerning this article. Our thanks also to Dr Trevor Russell Smith for his help in navigating some parts of Monte's Latin.

${ }^{1}$ Eric Burkart, 'Body Techniques of Combat: The Depiction of a Personal Fighting System in the Fight Books of Hans Talhofer (1443-1467 CE)', in Killing and Being Killed: Bodies in Battle. Perspectives on Fighters in the Middle Ages, ed. by Jörg Rogge, (Bielefeld: Transcript Verlag, 2017), pp. 109-30, p. 122; Jeffrey L. Forgeng, 'Owning the Art: The German Fechtbuch Tradition', in The Noble Art of the Sword: Fashion and Fencing in Renaissance Europe, ed. by Tobias Capwell (London: Paul Holberton, 2012), pp. 164-75.

2 A variety of both specialised and non-specialised works in the past century have dealt with the nomenclature of staff weapons. The inherent problem of these studies is the inconsistency of the terminology used to describe the same object, whether writing in English, Italian, German or French, or using terminology from one language whilst writing in another. Authors such as Stone, Ellehauge, Troso, and Waldman have all discussed the problem of terminology, but it is nearly impossible to produce a finite solution. The inconsistencies among even these specialised works only serve to emphasise the problem. See George Cameron Stone, A Glossary of Construction, Decoration and Use of Arms and Armor in All Times Together With Some Closely Related Subjects (New York: Jack Brussel, 1961); Martin Ellehauge, Certain Phases in the Origin and Development of the Glaive (København: Norlundes Bogtrykkeri, 1945); Mario Troso, Le armi in asta: Delle fanterie europe (Novara: Instituto Geografico De Agostini, 1988); John Waldman, Hafted Weapons in Medieval and Renaissance Europe: The Evolution of European Staff Weapons Between 1200 and 1650 (Leiden: Brill, 2005).

236 Acta Periodica Duellatorum 7(1), 2019, Proceedings of the conference The Art of fighting of Pietro del Monte (2018) 
process, such as reinforcing metal strips called langets. On occasion the shaft is made of either steel, or other metals, and the head itself can also include wooden parts. The length of the shaft varies depending on the category of the individual staff weapon and can be from one up to six metres. Additional parts may be attached to the weapon; these may include a spike on the lower end of the shaft, one or two protective hand-guards, or a means of safely securing the head to the shaft. The utility of staff weapons revolves around the reach they can provide to the user, as well as the different offensive potentials based on the technical characteristics of the weapon's head. Their versatility depends on these characteristics and can potentially allow the user to perform a succession of hits with the consecutive use of different features, or complex actions such as disarming, tripping, tangling and pushing. The aim of the wielder is to increase their threat by fighting at range and utilising the increased power deriving from the kinetic energy produced through perpendicular thrusts and centrifugal strikes. Staff weapons can be devastating against both infantry and cavalry, as most were designed to penetrate armour. Their length allowed the user to fight enemies on foot from distance, withstand a cavalry charge, or even cut down a mounted opponent. At the same time their increased length was also a source of weakness as they could not be used as effectively in close quarters. ${ }^{3}$

Monte's definition of what constitutes a staff weapon shows the problems inherent in using contemporary written sources to produce typologies; despite his reputation for detail, it is far briefer and less comprehensive than one might expect. When describing the pollaxe, Monte states that the weapon "is made of iron and wood and so is reckoned among the staff weapons", leaving one with the impression that these are the sole attributes needed for a weapon to be classified as a staff weapon. Regarding the qualities of the pollaxe itself, Monte characterises it as being "somewhat taller than a man. The upper part looks something like a hammer, but the top has a stout point, and one side of the hammer is blunt, the other sharp". He further suggests that there ought to be another point at the heel of the shaft, as this end is often used in combat. ${ }^{4} \mathrm{~A}$ singular comparison can be made with the terminology used by Le Jeu de la Hache, which employs consistent

${ }^{3}$ Iason-Eleftherios Tzouriadis, 'The Typology and Use of Staff Weapons in Western Europe c. 1400 - c. 1550’ (unpublished PhD thesis, University of Leeds, 2017), pp. 4-6.

4 "Aza vulgariter assumpta ferrum et lignum continer et sic inter arma inhastata intelligitur. In longitudine est aliquanto maior homine: in superiori parte se habet quodammodo ut martellus nisi quod superius fortem habet cuspidem et una pars martelli est obtusa: alia vero acuta. In inferiori parte que calx vocatur alia cuspis inest quoniam sepissime cum calce aze decerrarideber". Pietro Monte, Exercitorum atque artis militaris collectanea in tris libros distincta (Milano: Giovani Angelo Scinzenzlar, 1509), fol. 7v; Pietro Monte, Pietro Monte's Collectanea: The Arms, Armour and Fighting Techniques of a Fifteenth-Century Soldier, trans. Jeffrey L. Forgeng (Woodbridge: Boydell, 2018), pp. 3536. An additional translation of the Collectanea was recently published online by Mike Prendergast and Ingrid Sperber. This translation can be accessed online at http:/www.mikeprendergast.ie/monte/. Whereas Forgeng has stated that his translation is occupied with presenting what Monte intended to say, Prendergast and Sperber have produced a more literal translation designed with the historical European martial arts practitioner in mind. This article uses the translation of Forgeng throughout. 
terms throughout for the constituent parts of the pollaxe. ${ }^{5}$ Despite Monte's pollaxe lacking any form of axe head, this is far from unusual with the inclusion of a pollaxe with an actual axe head is very rare in the fight book corpus. ${ }^{6}$ What is more unusual is the suggested length of Monte's pollaxe; this is clarified again later as being the length of a man plus his hand to reach the hammer, with the spike extending further above this. This is the longest pollaxe described in the entire corpus of the fight books, and indeed longer than any extant pollaxe by some stretch, probably due to Monte's insistence that the pollaxe ought to be able to safely strike any target, including the feet. ${ }^{7}$ Monte emphasises the value of practicing with the axe to improve footwork and spatial awareness. The length and potential use of the weapon requires agility as well as the ability to learn to move laterally. He also mentions that practice with the two-handed sword can also help towards the same goal. ${ }^{8}$ This passage encapsulates some fundamental ideas about martial practices and combat, and at the same time both Monte's awareness and will to communicate them to the reader.

In his descriptions of other staff weapons Monte advocates that the ideal length of a partisan is a little longer than a man, and that its head resembles the blade of an ancient

5 Paris, Bibliothèque nationale de France, MS Français 1996. For the most recent translation of the text, see Olivier Dupuis and Vincent Deluz, 'Le Jeu de la Hache: A Critical Edition and Dating Discussion', Acta Periodica Duellatorum, 5th ser., 1 (2017), 3-62. This edition also contains a glossary of the terms used in the manuscript, including for the various aspects of the pollaxe and ways of fighting with it. See also Sydney Anglo, 'Le Jeu de la Hache: A Fifteenth-Century Treatise on Chivalric Axe Combat', Archaeologia, 109 (1991), 113-28. Whilst the translation of Dupuis and Deluz is more precise than Anglo's, both introductions to the source raise interesting questions about the text.

${ }^{6}$ For illustrations of pollaxes in fight books that lack an axe head, see Fiore dei Liberi, Fior di Battaglia, c. 1409 (Los Angeles, J Paul Getty Museum, MS Ludwig XV 13), fols 35v-37r; Hans Talhoffer, 1467 (München, Bayerische Staatsbibliothek, Cod.icon.394a), fols 41r-53r; Paulus Kal, c.1470 (München, Bayerisches Staatsbibliothek, Cgm 1507), fols 37v-42v. The most detailed source for combat with pollaxes, Le Jeu de la Hache, is also of this variety. See Dupuis and Deluz, 'Le Jeu de la Hache', pp. 4-5. A rare illustration of a fifteenth-century fight book depicting the pollaxe as having an axe head is to be found in a manuscript by Peter Falkner. See Peter Falkner, Kunste zu ritterlicher were, c. 1495 (Wien, Kunsthistorisches Museum, MS KK5012), fol. 63r. The problematic nature of the term 'pollaxe', particularly for weapons with no axe element, has been discussed by Tzouriadis, who favours the term 'axe-hammer group' for the wider weapon category, with appropriate sub-groups based on technical characteristics; see Tzouriadis, 'The Typology and Use of Staff Weapons', pp. 226-40. The term pollaxe is used in this article as the most popular term currently used in secondary literature.

7 "Aza sive tripuncta in longitudine usque ad martellum ex quantitate unius manus esse debet longior homine ipsam deportante: ut per totum attingere queat absque quod ad feriendum pedem alterius inclinet per tantam terre distantiam sicuti persona nostra longa est". Pietro Monte, Exercitorum, fol. $30 \mathrm{v}$; "The length of the pollaxe to the hammer should be a hand longer than the man who carries it, so that he can reach everywhere: otherwise in order to strike the opponent's foot we must lean over such a distance of ground as our body is long". Pietro Monte, Collectanea, p. 112.

8 Pietro Monte, Collectanea, p. 137. 
sword, but shorter and wider. ${ }^{9}$ After having covered the use of the axe and the partisan Monte only briefly touches on the uses and forms of the bill (ronca) and the halberd. The ronca, or bill, is described as being between the partisan and pollaxe, as somewhat like a pollaxe but with points on the side and a stronger point at the head. ${ }^{10} \mathrm{He}$ advocates using them in a manner between the axe and the partisan, primarily as a thrusting weapon. Monte's inclusion of material relating to the bill moves away from and supersedes that which is offered by fifteenth-century authors, whilst acting as a precursor for later sixteenth-century works. ${ }^{11}$ One of the most interesting parts of Monte's material concerning staff weapons centres around the spetum. The weapon that he describes has a long, sharpened point and at its base two sharp wings facing upwards in the shape of a bow. ${ }^{12}$ This description can fit what is more widely described in scholarship as a spetum or chanve-souris, but it can also describe a corseque. Regardless of typology, the use of the weapon remains the same. Monte praises the parrying capabilities of the weapon, as well as its capacity to trap the opponent's weapon. He provides instructions for scenarios where two weapons of this type are facing each other, as well as for fighting with the spetum against other types of weapons such as the spear, the jineta and the partisan. The spetum is described as an all-around good weapon against different arms, except for the pollaxe, which has the advantage in parrying and can overpower the user of the spetum. One of the most interesting details is Monte's advice on the defensive equipment one

9 "Partisana vulgariter quoque dicta telum pariter cum fustibus est: et paulo maior quam homo sublevata manu attingere potest: cuius ferrus: tanquam ferrum ensis antique lati esse videtur. Ac ferrus partisane brevius est tamen larius ex ambabus partibus scindit et cuspidem habet". Pietro Monte, Exercitorum, fol. 7v; "The partisan [partisana], also so named in the vernacular, is a spear likewise among the staff weapons. It is a little longer than a man can reach with his uplifted hand. Its head looks like the blade of an ancient broadsword, but the head of the partisan is shorter and wider. It cuts on both sides and has a thrusting tip". Pietro Monte, Collectanea, p 36.

10 "Rhonca est fere sicut partisana. Sed quasdam cuspides ex transverbo habet et etiam in parte superiori fortiorem punctam tenet quam partisana: quapropter rhonca inter partisanam et azam operanda est". Pietro Monte, Exercitorum, fol. 7v; "The ronca is somewhat like a partisan, but it has points on the side and also has a stronger point at the tip than a partisan, so the ronca functions like a cross between a partisan and a pollaxe". Pietro Monte, Collectanea, p. 36; "The [halberd] has a head for cutting almost like a butcher's axe, and a thrusting tip, and another small point going laterally. The ronca has a longer head, but not so broad". Pietro Monte, Collectanea, p. 126. The authors have not provided a Latin transcription for this quotation as this part of the manuscript examined has been damaged. It can be found on fol. $34 \mathrm{v}$. For a detailed typological analysis of the different types of the bill based on written and iconographical sources see Troso, Le armi in asta, pp. 135-254.

11 Peter Falkner, Kunste zu ritterlicher were, fol. 64v; Antonio Manciolino, Opera Nova (Venice: Nicolo d'Aristotile detto Zoppino, 1531), fol. 52v; Achille Marozzo, Opera Nova (Bologna: D. Antonio Bergolae, 1536), fols 88v-90r.

12 "Spetum comuniter cum puncta iacitur licet aliquas acutas aures teneat: ac revolutas in modum medii arcus anterius: que de reverso: aut sectione abscindere possunt et arma fortis". Pietro Monte, Exercitorum, fol. 34v; "The spetum usually attacks with the point, although it has a pair of sharp ears, each curbing forward like a half-bow, and able to slice with a reverse or a cut". Pietro Monte, Collectanea, p. 126: 
should use against the spetum. He advocates the use of mail gauntlets to protect the hands against slicing strikes from the spetum's wings and a breastplate. ${ }^{13}$ Finally, Monte dedicates only a short passage to the use of the staff, which he also calls baston. The practice of the staff is advocated in order to drill body motion through the rotation of the arms. Monte however advises against this use of the weapon in combat in favour of the material he already covered for the axe. ${ }^{14}$

Even though these definitions are somewhat brief, their inclusion is of importance given the aforementioned confusion in scholarship regarding the typology of staff weapons, which are themselves infrequently defined in historical literary sources. It should be noted, however, that even Monte does not provide a definition and description for every staff weapon he refers to, omitting these for the jineta, the long spear, and the pike. Monte's persistence in providing clear definitions for various forms of weapons nevertheless shows an observational, analytical approach to martial affairs, creating a solid frame upon which he builds on in addressing the practical use of weapons. ${ }^{15}$

\section{THE MILITARY AND MARTIAL CONTEXTS OF STAFF WEAPON USE IN THE FIFTEENTH AND SIXTEENTH CENTURIES}

Another subject that needs to be examined is the historical military context of Monte's work, and how its influence is reflected in Monte's writings on staff weapons. The fifteenth century witnessed significant changes in the conduct of war and military organisation, with professional infantry having an increased importance on the battlefield, and armies usually fighting with combined forces of infantry, cavalry, and artillery. ${ }^{16} \mathrm{By}$ the end of the fifteenth century professional Swiss, German, and Italian infantry soldiers

\footnotetext{
13 "Faciliter spetum potest contra quamcunque armam confligere. In cuius tamen oppugnantiam assumende sunt chirothece malliole de apprehensio ne propterea quod aures speti fecant". Pietro Monte, Exercitorum, fol. 34v; "The spetum can easily fight against any weapon. In opposing it we should wear mail gauntlets for holding it, since the ears of the spetum can slice". Pietro Monte, Collectanea, p. 127.

14 Pietro Monte, Collectanea, p. 117.

${ }^{15} \mathrm{It}$ is worth mentioning that although Monte is desirous of creating a solid foundation in his first book which can be built upon in the second, he does not always fulfil this goal. Several important staff weapons are, for example, only introduced in book two. Instead of creating the intended linear approach for the reader, the reader must traverse between books in order to explore all staff weapon content. For Monte's explanation of the relationship between his first and second book see Pietro Monte, Collectanea, p. 97.

${ }^{16}$ For the origins of these changing military trends, see Kelly DeVries, Infantry Warfare in the Early Fourteenth Century: Discipline, Tactics, and Technology (Woodbridge: Boydell, 2000). For their full realisation in the fifteenth century see Bert Hall, Weapons and Warfare in Renaissance Europe: Gunpowder, Technology, and Tactics (Baltimore: John Hopkins University Press, 1997) and Michael Edward Mallet and Christine Shaw, The Italian Wars, 1494-1559: War, State and Society in Early Modern Europe (Harlow: Pearson, 2012).
} 
- the choice of the word mercenary is avoided deliberately - were well-sought after during the continuous military conflicts that occurred in central and western Europe. ${ }^{17}$ Swiss Reisslaufers and German Landsknechts became renowned for their military efficiency while using a variety of staff weapons, predominantly pikes, but also halberds and bills. These changes in military organisation and conduct developed further in the first half of the sixteenth century with armies including specialised light and heavy infantry, light cavalry, artillery, handguns, and larger contingents of general infantry armed with various staff weapons (fig. 1). Artistic production was also affected by these shifting trends: works of art from this period reflect not only military composition but also the equipment of soldiers in detail as a result of the artistic transition to and focus upon realism and mannerism (fig. 2). ${ }^{18}$

17 The subject of defining medieval and renaissance mercenaries has been a subject of debate in military history scholarship. The changing conduct of war in Europe during the examined chronological framework affected military organisation as the result of the emergence of professional armies. For further discussion on this complicated matter see John R. Hale, War and Society in Renaissance Europe, 1450-1620 (Montreal: McGill-Queen's University Press, 1998); Frank Tallett and David J. B. Trim (eds.), European Warfare, 1350-1750 (Cambridge: Cambridge University Press, 2015); John France (ed.), Mercenaries and Paid Men: the Mercenary Identity in the Middle Ages: Proceedings of a Conference Held at University of Wales, Swansea, 7th-9th July 2005 (Leiden: Brill, 2008).

${ }_{18}$ Renowned artists of the period discussed, such as Hans Holbein the Younger and Lucas Cranach the Elder, often produced works with detailed depictions of war; these sometimes included overviews of battles and battlefields, or detailed studies of soldiers. Artists such as Urs Graf and Niklaus Manuel also portrayed soldiers of this period, often with highly detailed equipment. Their perspective is invaluable to this type of study because they both served as mercenaries for several years. Scenes that include soldiers, often as part of artwork including a religious theme, show in detail their arms and armour; a comparison of similar narrative scenes, such as the Crucifixion, shows the shifting trends in equipment through different periods, at the very least from a fashion and pictorial scope. For some suggested readings on artistic movements and the artists discussed see Giuliano Briganti, La maniera italiana (Rome: Editori Riuniti, 1961); Ernst Hans Gombrich, The Story of Art (London: Phaidon Press, 1995); Erwin Gradmann, Urs Graf (Basle: Holbein Publishing Co., 1942); John R. Hale, Artists and Warfare in the Renaissance (New Haven: Yale University Press, 1990); Burkhard Shwetje and Flavio Febbraro, How to Read World History in Art: From the Code of Hammurabit to September 11 (London: Thames and Hudson, 2010); Albrecht Dürer, Woodcuts and Wood Blocks, ed. by Walter L. Strauss (New York: Abaris Books, 1980). 


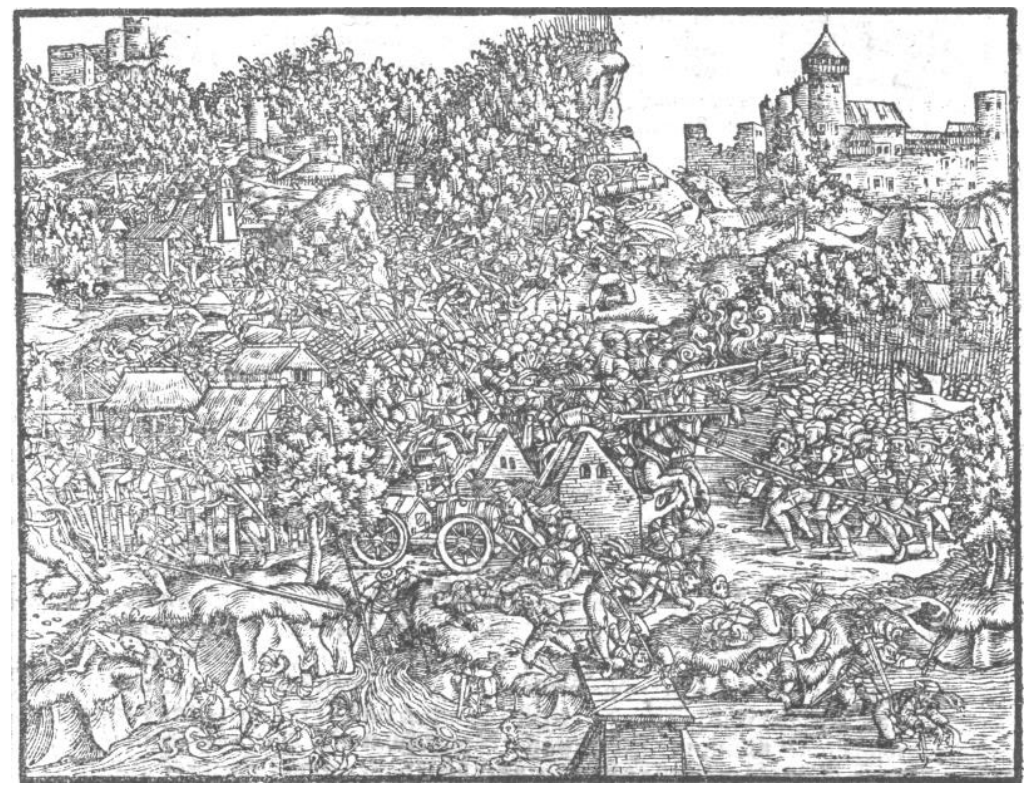

Fig. 1: A woodcut of the Battle of Dornach (1499), displaying the deployment of artillery, cavalry, and infantry armed with varying forms of arms and armour. Battle of Dorneck, woodcut, c. 1499, Kupferstich Kabinett, Basel.

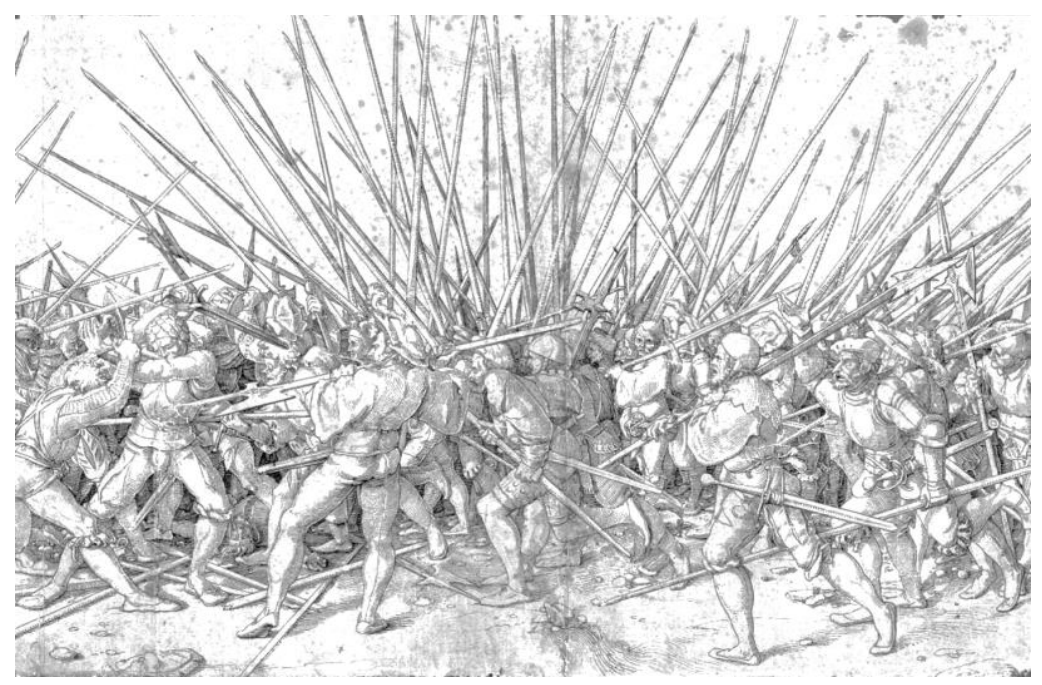

Fig. 2: An detailed display not only of different staff weapon types from the period discussed, but also of the multitude of their uses and means of handling. Hans Holbein the Younger,

Scblechten Krieg (Bad War), pen on paper, early sixteenth century, Grafische Sammlung Albertina. 
From a commercial, social, and military perspective it is sensible to assume that one of the reasons that fifteenth-century fight books included staff weapon material was to align with the corresponding inclusion of these weapons in everyday martial culture and the subsequent aforementioned artistic production. Besides the description and depiction of techniques with staff weapons being used by two people using the same equipment, some fight books include asymmetrical weapon techniques with one person using a spear against one or more riders. ${ }^{19}$ This theme appears to be a rather peculiar inclusion within the genre, especially when considering that the dominant trope even in the case of most staff weapons is fighting with identical equipment, and with both fighters either on foot or horseback (although obviously not the latter in the case of staff weapons). A potential explanation is that these techniques, more so than the rest of all the material included in fight books from the fifteenth as well as from the sixteenth century, reflect the martial reality of the examined period, particularly in a military context. Monte goes further with this type of approach, offering advice as to how a man on foot should fight against a rider, as well as describing the importance of composure, agility, the horse as a threat, and the variable created by different types of armour worn by either fighter. ${ }^{20} \mathrm{He}$ also takes for granted that the fighter on foot is using a medium spear. This is interesting considering that the most common weapon for infantry during his lifetime would indeed be the spear, but the most popular choice would be a longer version, or the pike. It is possible that this choice by Monte was a deliberate one designed to reduce the military factor of this subchapter and focus on the medium spear which, based on other subchapters, he seems to favour over other forms of the weapon. In this way Monte balances these chapters between military reality and martial practice.

Another subchapter by Monte that could also be interpreted to have been influenced by military practices is one where he offers advice on fighting against an opponent with a weapon of different size. ${ }^{21}$ While this is potentially useful for combat between individuals, when applied to staff weapons it can certainly be interpreted as preparing for the reality of the battlefield of this period, where different staff weapons were used simultaneously and against one another (see figs 1 and 2). Other authors such as Falkner included aspects of fighting with different staff weapons between two combatants, considering the equipment and techniques interchangeable, but Monte focuses explicitly on the different length between weapons. There is no explicit way, however, to prove that fight books in general, or Monte in particular, deliberately included material that was directly reflecting warfare. Considering that the genre was part of the general martial culture of its period it is a safe assumption that it was influenced by the development of warfare, especially in regard to the equipment included in its corpus throughout the fifteenth and sixteenth centuries. Monte's detailed thought on all martial matters he included in the Collectanea leaves no space to assume he did not consider warfare as the source of his fighting

\footnotetext{
19 Two examples from the fifteenth century include Fiore dei Liberi, Fior di Battaglia, fol. 46r, and Die Blume des Kampfes, c.1420 (Wien, Österrische Nationalbibliothek, Cod.5278), fol. 176r.

20 Pietro Monte, Collectanea, pp. 129-130.

21 Pietro Monte, Collectanea, p. 128.
} 
techniques, as is only to be expected of a condottiero. The choice of equipment itself, particularly the partisan, the pike, the bill and the halberd, perfectly depicts the majority of staff weapons used in a military context in the late fifteenth and early sixteenth century.

\section{THE RELATIONSHIP BETWEEN STAFF WEAPONS IN MONTE'S COLLECTANEA AND THE WIDER FIGHT BOOK GENRE}

It is through his treatment on the use of the pollaxe as the exemplar weapon for fighting with staff weapons that Monte's approach can be linked to previous entries in the fight book corpus. He writes that "with any haft or staff weapon we can play most securely by observing the play of the pollaxe". 22 Previous authors, such as that of the anonymous Le Jeu de la Hache, shared a similar approach, although went further by arguing that the play of several weapons derives from that of the axe. ${ }^{23}$ In a similar manner to Monte, other authors such as Hans Talhoffer and Paulus Kal include plays with the axe, or spear, to represent the use of staff weapons as a single weapon group, whilst Peter Falkner shows a range of weaponry in his section on staff weapons. ${ }^{24}$ Regardless of this inclusion, staff weapons only appear briefly in fight books from the first three quarters of the fifteenth century, and their use is often described as deriving from the use of the sword. This is seen in the anonymous fourteenth-century $3227 \mathrm{a}$, which in its single folio pertaining to fencing with the staff indicates that the art of fighting with the staff is taken from the sword. ${ }^{25}$ The same notion can be seen in the works of Fiore dei Liberi. In his section on

22 "Cum quacumque arma inhastata: seu suste tutius ludit: quam aliter viam tricuspidis observando". Pietro Monte, Exercitorum, fol. 29v; Pietro Monte, Collectanea, p. 110.

23 "And because of this, let every man, noble of body and courage, naturally desire to exercise and enable himself in a virtuous and honourable occupation. And principally in the noble feat of arms, that is to say in axe-play, from which proceed and depend several weapons above-named". The aforementioned weapons include the half pike, the dagger, the great sword and the short sword. Dupuis and Deluz, 'Le Jeu de la Hache', 33.

24 Hans Talhoffer, 1467 (München, Bayerische Staatsbibliothek, Cod.icon.394a), fols 41r-53r; Paulus Kal, c.1470 (München, Bayerisches Staatsbibliothek, Cgm 1507), fols 37v-42v. An interesting exception to this can be found in Talhoffer's 1459 fight book, where a short series of folios depict different staff weapons being used against swords. These are primarily variants of spears, but one folio shows a halberd being used. Hans Talhoffer, 1459 (København, Det Kongelige Bibliotek, MS Thott.290.2º, fols 75r-78v; Peter Falkner, Kunste Zu Ritterlicher Were, fols 62v-65r.

25 "And that the fencing with the staff is taken from the sword, and as one fights with the sword, so he also fights with the staff. And the principles that appertain to the sword, such as Before, After, Cunning, Prudence, etc. they also appertain to the staff". Nurnburg, Nationalmuseum, Cod. Hs. 3227 a c. 1389 , fol. 78r. The dating of this manuscript to the late fourteenth century, specifically 1389, is an uncertain one. For the dating of 3227a see Eric Burkart, 'The Autograph of an Erudite Martial Artist: A Close Reading of Nuremberg, Germanisches Nationalmuseum Hs. 3227a', in Late Medieval and Early Modern Fight Books: Transmission and Tradition of Martial Arts in Europe (14th - 17th Centuries), ed. by Daniel Jaquet, Karin Verelst, and Timothy Dawson (Leiden: Brill, 2016), pp. 45180, p. 453 
the use of the pollaxe in armour, as seen in the Getty manuscript, Fiore depicts six poste and eight plays. Each of these starting positions can be seen earlier on in the manuscript in the sections appertaining to the use of the sword, both in and out of armour. ${ }^{26}$ The techniques are treated in a similar manner, such as lifting an opponent's visor before striking the face, although Fiore is also aware of different ways in which staff weapons can be used given their increased length, including as a lever. ${ }^{27}$ Monte, on the other hand makes clear distinctions between the sword and the axe. Although he says that other staff weapons are used in a manner akin to the pollaxe, he links the play of the two-handed sword to that of shorter weapons. It should be noted, however, that despite a different approach in how the weapons are used, Monte still advocates a similar approach for both in practice, often recommending feints and striking twice - once to provoke an opponent and the second to lead in to a thrust. ${ }^{28}$

The Collectanea are also linked to the later, sixteenth-century fight books through their pragmatic content, but not necessarily that relating to the axe. Besides the emphasis given to the spear and staff, which is a common phenomenon in fight books from the late fifteenth all the way to the end of the sixteenth century, Monte also includes extensive examples of the use of the partisan, which appears to have been particularly fashionable in Italian fight books during the first half of the sixteenth century. ${ }^{29} \mathrm{He}$ also describes combat with the partisan and a rondache, two partisans and a rondache, and two partisans. ${ }^{30}$ On occasion he also mentions details on the combat between two different staff weapons. ${ }^{31}$ This is comparable to the content of fight books both before and after this career, and to the fight books of Italian writers such as Marozzo and Manciolino. ${ }^{32}$ The weapons they cover are roughly the same as those described by Monte, and their approach

\footnotetext{
${ }^{26}$ Fiore dei Liberi, Fior di Battaglia, fols 35v-36r, 23v-24v, and fol. 32v.

${ }^{27}$ Fiore dei Liberi, Fior di Battaglia, fol. 36v.
}

28 "Nec aliter de pede ad caput iacus est fiendus prolongando azam ad feriendum cum martello: seu puncta obtuse per superiorem partem: brachia in nobisipsis sunt recolligenda. Alter enim vadit ad cooperiendum se: et eodem tempore est locus nocendi cum puncta ad stomachum: et revertendo iterum ad nos regendum velociter: tunc generalis regula est ocius cum calce punctam iacare". Pietro Monte, Exercitorum, fol. 30r; "When we extend the pollaxe to strike high with the hammer, we should gather in our arms, for as the opponent goes to cover himself, there is an opportunity to hit him with a thrust to the stomach; and returning to cover ourselves quickly, then it is a general rule to deliver a quick thrust with the heel". Pietro Monte, Collectanea, p. 111; "Principales vero ictus duo ascendentes sunt ex quacunque parte nostrorum laterum: et ultimus cum stocchata: vel puncta finire debet: et quod exemplo ad nos cooperiendum redeamus: aut ad aliquam partem cum aliquo duplici ictus tangendam". Pietro Monte, Exercitorum, fol. 32r; "The principal blows are two rising cuts, one from each side, finishing with a thrust; and at once we should return to cover ourselves, or hit somewhere else with a double blow". Pietro Monte, Collectanea, p. 117

${ }^{29}$ Pietro Monte, Collectanea, p 124, p. 128. For some Italian fight books containing partisan material see Antonio Manciolino, Opera Nova, fols 59v-60v, and Achille Marozzo, Opera Nova, fols 81r-90r.

30 Pietro Monte, Collectanea, p. 124, p. 128.

31 Pietro Monte, Collectanea, pp. 126-128.

32 Antonio Manciolino, Opera Nova, fols 58r-63v; Achille Marozzo, Opera Nova, fols 81r-90r. 
is similar. They both split the techniques between different weapons, particularly spears and bladed staff weapons, but usually agree on the interchangeable nature of the material they present. ${ }^{33}$ Compared to these writers Monte comes across as less didactic and structured in the description of his techniques; he is, however, usually superior at explaining the context of their use. Another similarity between Monte and the sixteenthcentury masters is the presentation and form of the staff weapon's initial guards and an affinity for feints.

As previously discussed, Monte's specifically armoured context of his pollaxe is almost identical to the armoured pollaxe fighting as presented in fifteenth-century fight books. His overall staff weapon content, however, is clearly closer to sixteenth-century fight books, making this aspect of Monte's work truly a hybrid treading between the genre's tradition over the fifteenth and sixteenth centuries. It is worth calling attention to the fact that the martial frameworks and descriptions of arms is not the only thing which separates Monte's work from most others. An examination of the language and the manner in which he presents the matter of his chapters reveals that his tone is more observational than pedagogical, especially when compared to the mnemonic Merkverse of the Liechtenauer tradition, or didactic approach of Le Jeu de la Hache. ${ }^{34}$ In most cases he suggests actions through what ought to be interpreted as his previous practical and observational experiences, although doing this without claiming unique expertise on the subject; unlike some other fight book authors whose claims to skill at arms are found in their own works, there are multiple examples of Monte's brilliance to be found elsewhere. ${ }^{35}$ Throughout his work, specifically in the parts where he talks about staff weapons, Monte's descriptions of weapon use sometimes resembles a handbook or encyclopaedia, not because of the didactic tone or content, but because of the inclusion of peripheral information concerning his discussed subject, such as brief discussions on the terminology of a weapon, and its technical details such as its length, a comparison to other equipment, or the martial contextualisation in different cultures; although the

33 Antonio Manciolino, Opera Nova, fols 58r-59v; Achille Marozzo, Opera Nova, fols 80v-90r.

${ }^{34}$ Deacon has previously argued that Le Jeu de la Hache ought to be considered one of the first fight books created with didactic purposes in mind. Jacob Deacon, 'Prologues, Poetry, Prose and Portrayals: The Purposes of Fifteenth-Century Fight Books According to the Diplomatic Evidence', Acta Periodica Duellatorum, 4th ser., 2 (2016), 69-90 (79-81).

35 One of the most brazen examples of this are to be found in the Getty manuscript of Fiore dei Liberi. Fiore claims at the start of his manuscript that, jealous of his success, five other masters had at one point or another throughout his career (it is unclear if the five acted together or alone) conspired against him and challenged him to fight without harness, using sharp swords. Fiore claims to have escaped these duels unscathed, but there is currently no further evidence of them having taken place. Admittedly, some of Fiore's students did prove to be successful fighters - Galeazzo de Mantua overcoming the renowned French champion Boucicaut on two separate occasions - but to what extend the credit for this can be placed at the feet of Fiore is unclear. Fiore dei Liberi, Fior di Battaglia, fol. 1v. For the duel between Galeazzo and Boucicaut, see Massimo Malipiero, Il Fior di battaglia di Fiore dei Liberi da Cividale (Campofòrmido: Ribis, 2006); pp. 55-58; For a summary of Monte's military career described through the eyes of others, see Pascal Briost, 'Contextualising Pietro Monte's Military Career in Italy', also in this volume. 
authors of the present article are reluctant to apply the term "fencing manual" as an alternative to fight book, there is a case to be made that this is exactly what Monte has produced. At first glance Monte gives advice and instructions on fighting with staff weapons; a closer look, however, reveals that he attempts to recreate the context of their use alongside their actual use in order to allow the reader to partake in his observations.

\section{$V$. THE USE OF STAFF WEAPONS IN MONTE'S COLLECTANEA}

Monte's writings dedicated to the use of staff weapons are not concentrated in just one section, but instead scattered throughout the Collectanea. This is not the result of random, haphazard, or uncaring placement, but rather evidence of Monte's attempt to link the use of different staff weapons to other weapons used in similar contexts within his work. Staff weapon material is generally divided by Monte according to the weapon type, many of them explicitly overlapping one another, with differences highlighted by the author.

By far the major distinction made by Monte is that between the use of different varieties of spears and other, usually bladed, weapons, such as the pollaxe, the halberd, and the partisan. These differences revolve around Monte's suggested initial grip of the weapons and stance patterns, and the fact that the latter group of weapons is examined under the assumption that they are used primarily in an armoured context, although the information appearing in these two wider groups is often overlapping as well as interchangeable. This is a direct result of Monte's focus on staff weapons having thrusts as their primary offensive use, in addition to their additional features for secondary and tertiary uses. ${ }^{36}$

Another factor stressed by Monte is the importance of motion economy, reducing fatigue and unnecessary movements - an especially important consideration given his focus on the often armoured context of fighting with staff weapons. Examples of this offered by Monte include his advice that combatants should lead with the right foot forward and move in a circular motion while avoiding back-stepping. ${ }^{37}$ Should this become unavoidable, and the combatant needs to create distance between he and his opponent,

\footnotetext{
36 "Et pro maiori parte cum punctis aze tangere debemus. Martellus enim sive pars obtula omnino in rebus fortibus valet ad signamdum vel percutiendum. Sed ad decartandum meliores sunt acuti cuspides". Pietro Monte, Exercitorum, fol. 9r; "Generally we should hit with the point of the pollaxe: the hammer is fine for feinting or striking when you need it, but in earnest combat sharp points are better". Pietro Monte, Collectanea, p. 42.

37 "Dum contingit pedester cum armis albis atque cum acha sive tricuspide decertare pauca hic sunt operanda: in primis enim circumcirca est ambulandum super latus: quod aliqualiter alterum precedit: retro vero nunquam decet ambulare nisi quandoque unum pastum: tantum ut ictum alterius inanis transeat: aut ingrediendo adversarius quod habeamus tempus accommodatum ad agendum ictum nosrum contra ipsum: sed similes passus in modo transverso: sive ad latera est melius". Pietro Monte, Exercitorum, fol. 30v; "When we have to fight on foot in white armour and with the pollaxe, there are a few things we should observe. First, we should step around on the side that we have forward, but we should never step backward, except occasionally one step, to let the opponent's blow go past us, or when the opponent steps in, to give us enough time to deliver our blow against him. But it is better to do such steps to the side". Pietro Monte, Collectanea, p. 113.
} 
Monte suggests a thrust with the heel of the weapon, designed to keep the opponent at range, or strike them should they attempt to remain at close distance..$^{38}$ Other elements which are often referred to again and again in different sections are the displacement of the feet as an accompaniment to parrying, the use of the shaft to protect the core of the body before attacking, and launching strikes from both sides. ${ }^{39}$

In discussing the preparation to begin such attacks, Monte suggests three initial positions, or guards, for use with staff weapons. These include holding the weapon low and horizontally, pointing it downwards towards the opponent, high with the hands extended, and abreast in different angles, depending on the subsequent technique. ${ }^{40}$ The description of the second resembles material from the middle of the sixteenth century such as those seen in Meyer's Gründtliche Beschreibung der Kunst des Fechtens, while the abreast position appears to be closer to fifteenth-century fight books such as Paulus Kal; such a comparison is another indication of the middle point that Monte's work occupies. ${ }^{41}$ The abreast position of the staff weapon is also suggested by Marozzo for the use of the partisan, the spetum, and the bill. ${ }^{42}$ Additionally, Monte mentions an important detail regarding the positioning of the spetum in relation to the opponent, which should be held pointing straight to the opponent rather than to the side. This relates to the manner that

38 "Nam quotiescunque vult ictum nostrum repare firmiter manendo: aut se nobiscum iungere: possumus ipsum conto percutere duos: aut tres ictus agendo absque quod manus firmentur: et parumper retrocedere oportet: sunt assidue instruendi: ac moderandi:pedes : et caput observerandum". Pietro Monte, Exercitorum, fol. 30r; "Whenever he wishes to parry our blow standing firmly, or tries to close with us, we can strike him with the lower end of the shaft, doing two or three little blows with our hands in continual motion, and we should step back a little; our feet should constantly be adjusting and responding". Pietro Monte, Collectanea, p. 111.

39 "Et quod armam defensibilem habeamus: vel qua cum illamet: qua offendimus reparare velimus semper tutius erit membrum effugere: in quo alter nos percutere volet: non quod in hoc terram perdamus: nisi quod nos non attingat: aut ictus adversantis incassum transeat. Nos quoque sepius retrahere oportet per unum passum a latere deviando. Et tunc ad discooperta loca inpugnantis ictus nostri iaciendi sunt minando ad unam partem cum dimidio ictu corporis ostentantionem faciendo: tamen tunc absque teli motione: ac deinceps sestinatim revertamur ad faciendum ex alia pre longum ictum". Pietro Monte, Collectanea, fol. 29v; "Even when we have a defensive arm, or when we try to parry with our offensive arm, it will always be safest to displace the body-part that the opponent seeks to hit - not that we should lose ground in this, but so that he does not hit us, or his blow goes past without hitting. Also we should often step away, displacing to the side with one pace, and then deliver our blows to the opponent's opening, threatening in one place, feigning half a blow with the body, but without moving the weapon, then quickly turning back to deliver a long blow from somewhere else". Pietro Monte, Collectanea, p. 110.

40 Pietro Monte, Collectanea, pp. 41-42 and pp. 110-14.

41 Joachim Meyer, Gründtliche Beschreibung der Kunst des Fechtens (Strasbourg: Thiebolt Berger, 1570), fols 3.16r -3.47r; Paulus Kal, Cgm 1507, fol. 37v.

42 Achille Marozzo, Opera Nova, fols 84r-90v. 
he describes parrying with different weapons, which in the case of the spetum is with the wings rather than with a side to side motion of the shaft. ${ }^{43}$

Monte is favourable towards feints with all staff weapons and he usually advises that the first strike in a sequence should always be weaker and used to either measure the opponent's reaction, or feint, and that the second strike ought to be stronger and delivered with greater intent. ${ }^{44}$ Often, his techniques with the pollaxe, which he presents as the cardinal staff weapon, include weak or strong strikes to the opponent's hands. ${ }^{45} \mathrm{He}$ also favours closing the distance and grappling with the opponent, which is a common theme throughout his work. ${ }^{46}$ Monte's staff weapon techniques can thus be characterised as a mix of two opposing elements: putting pressure on the opponent from different angles, and feinting to lead one's opponent into a disadvantageous position with proper footwork and weapon positioning that ends with thrusts to the opponent and using their own momentum against them.

A point worth expanding on is Monte's persistence regarding the use of the heel as the primary threatening feature of the pollaxe. The extensive use of the lower end of the shaft is a pattern extant in fifteenth-century treatises such as Le Jeu de la Hache, where the author instructs the reader to thrust roughly three times as often as any other technique. ${ }^{47}$ Fiore, on the other end of the spectrum, usually avoids the use of thrusts with the heel and favours thrusts with the spike on the upper end of the weapon. ${ }^{48}$ The use of the upper or lower thrusting element of a staff weapon is something examined by Tzouriadis in his doctoral thesis. The results of the examination of over 1,200 staff weapons, and

\footnotetext{
43 Pietro Monte, Collectanea, pp. 126-127.

44 Pietro Monte, Collectanea, p. 111.

45 "Agendo ictus nostros communiter leves: ac sepius adversantis manum prosequendo dum alia pars indiscooperta ostenditur". Pietro Monte, Exercitorum, fol. 9r; "Our blows should generally be nimble, often targeting the opponent's hand when no other part is exposed". Pietro Monte, Collectanea, p. 41.
}

46 Wrestling is the first form of martial arts to be covered by Monte in both his first and second books. It is clearly a skill he feels is vital to success in armed combat, as he frequently presents it as an option to the reader. Monte goes as far as describing wrestling as the "mistress" of martial arts: "Nulla enim alia industria proiiciendi delevitate: aut ludo armorum sive equitation docet ponere membra temperata: ac super seipsis ita ut in palestra sit: ac semper scire responsum dare ubi necessitas occurrit". Pietro Monte, Exercitorum, fol. 26r; "No other skill - neither throwing, nor acrobatics, nor play of arms, nor equitation - teaches us to temper and control our bodies like wrestling, and always to know how to respond where necessity arises". Pietro Monte, Collectanea, p. 99.

47 Jacob Deacon, 'The Pollaxe c. 1350 - 1550' (unpublished master's dissertation, Cardiff University, 2016), pp. 67-77. Deacon's work establishes an observable pattern in fifteenth-century fight books which shows an overwhelming reliance on thrusts when fencing with pollaxes. Alongside Le Jeu de la Hache, various other fight books, such as the works of Talhoffer, Kal, and Falkner also conform to this pattern, although with certain variances. Thrusts in Talhoffer's 1459 fight book, for instance, are primarily conducted with the head of the weapon, whilst the technique displayed more often than any other in his 1467 work involves hooking an opponent with the pollaxe, followed by throws. ${ }^{48}$ Fiore dei Liberi, Fior di Battaglia, fols. 36v-37r. 
particularly those that visibly have had their shafts replaced or have parts of them which have suffered damage both on the shaft or their metal components, as well as the conduct of theoretical stress-test simulations, demonstrated that staff weapons from the late fifteenth century onwards were used primarily for thrusting with the upper half of the weapon. ${ }^{49}$ This is particularly interesting in the case of weapons with accented horizontal features such as the halberd, the bill, and the pollaxe. It is interesting seeing that preliminary modern scientific attempts align with Monte's views on the use of a weapon, as well as those of the authors of other fight books, but it is important not to see the coincidence of the two data sources as conclusive, and more work should be conducted on the subject. ${ }^{50}$

\section{CONCLUSION}

The contextualisation of Monte's thoughts on staff weapons can, by and large, be seen to exist on two axes. These are based on geographical criteria and chronological frameworks relating to fight books created before and after the Collectanea. Only by assessing the details in Monte's content, and the structure of his approach, is it possible to better understand where to place Monte's work within the wider genre. As a rule, when it comes to fifteenthcentury texts dealing with staff weapons, fight books deal almost exclusively with an armoured context. The main weapon of choice is the pollaxe and its variations, although other staff weapons, such as different types of spear, are known to appear. In the first half of the sixteenth century the content and the approach to staff weapon fighting in fight books changes radically, largely because of the changes in their audiences and mediums.

Monte's approach is much closer to works that succeeded than preceded him. Some choices, it should be noted, echo fifteenth-century approaches; his staff weapon content stems from the axe as the exemplar weapon and is accompanied by advice for engaging in armoured combat. His approach to fighting, when viewed in light of his medium and audience, however, mainly reflects trends which came to be more popular in the sixteenth century; following his armoured combat introduction he describes features of unarmoured combat, particularly with the partisan and the spetum, as well as with the axe with such structures appear in the fight books of masters such as Manciolino and Marozzo. This resemblance in structure and content, and often to the aforementioned communication themes and devices, places Monte in a prominent place within the socalled Italian tradition.

${ }^{49}$ Iason-Eleftherios Tzouriadis, 'The Typology and Use of Staff Weapons', pp. 247-74.

${ }^{50}$ A quantitative comparison of techniques in these fight books, although demonstrative of general principles, should not be offered without a word of caution. The fact that three out of five pollaxe techniques involve thrusts for Fiore does not by any means equal that he is recommending that a student thrust $60 \%$ of the time. Also important to bear in mind is the number of techniques depicted. Le Jeu de la Hache is a much more reliable indicator than others because of the high number of techniques described, which is many times more than what is discussed in other fight books. 
Although a visionary who was praised by his contemporaries for his martial knowledge and prowess, Pietro Monte's legacy as a fencing master is a non-existent one, with no direct links to subsequent works as is so predominantly seen in the Liechtenauer tradition, or in the Dardi school. ${ }^{51}$ This lack of a clearly attested relationship between Monte and fight book authors simply serves to act as evidence of just how extraordinary his work is. By itself the sheer number of staff weapons classified, contextualised, and taught in the Collectanea is impressive enough, and this feat is made all the more impressive by the attention to detail throughout. Monte's work stands alone in the fight book genre, the author possessing unique attributes amongst those writing about arms, armour, and their use. He is first and foremost a scholar of arms and explores martial matters in a manner comparable to contemporary humanist scholars. Alongside the natural-philosophical questions he explores on the peripheries of martial culture, such as where men ought to be placed in battle depending on their balance of humours, his work follows a methodical approach, even when concerning the simplest of subjects, descriptions of objects, and their use. Comparable conclusions have been reached by writers such as Anglo and Fontaine, while Mondschein has also noted that Monte's work occupies a transitional period in fight books production in Italy during the first half of the sixteenth century. ${ }^{52}$

Often, the inclusion of staff weapons in a fight book can be interpreted as an outreach to the military culture of its period. In Monte's writing, the description of staff weapons and fighting with them is a natural progression of his content, and only part of his overall understanding of military matters, which is reflected throughout his work. More than any other fight book of its period the Collectanea outgrows its own genre and can be considered an almost academic study on fighting and martial thought. Staff weapons in Monte only represent a fragment of that study, but this article has highlighted how he considered and examined the military context of fighting more than any other fight book before him, and several after him.

51 Two such contemporaries who lauded the abilities of Monte were Baldassare Castiglione and Leonardo da Vinci. In The Book of the Courtier, Castiglione remarks that Monte alone is suitable for training people in bodily exercises, physical strength, and agility, being "the true and only master of every form of trained strength and agility". Baldassare Castiglione, The Book of the Courtier, trans. by Leonard Eckstein Opdycke (New York: Scribners, 1903), p. 173 and p. 33. Likewise, a note written by Leonardo da Vinci indicates that he intended to consult Monte regarding his efforts to calculate the trajectory of a dart as it was launched from a sling. For further details see Sydney Anglo, 'The Man who Taught Leonardo Darts: Pietro Monte and His Lost Fencing Book', The Antiquaries Journal, 69 (1989), 261-78.

52 Sydney Anglo, The Martial Arts of Renaissance Europe (New Haven: Yale University Press, 2000), p. 26; Marie-Madeleine Fontaine, Le Condottiere Pietro del Monte: Philosophe et Écrivain de la Renaissance, 1457-1509 (Geneve: Editions Slatkine, 1991); Ken Mondschein, 'The Italian Schools of Fencing: Art, Science, and Pedagogy', in Late Medieval and Early Modern Fight Books: Transmission and Tradition of Martial Arts in Europe (14th - 17th Centuries), ed. by Daniel Jaquet, Karin Verelst, and Timothy Dawson (Leiden: Brill, 2016), pp. 280-324, pp. 301-305. 


\section{BIBLIOGRAPHY}

\section{VII.1. Primary sources}

Achille Marozzo, Opera Nova (Bologna: D. Antonio Bergolae, 1536).

Antonio Manciolino, Opera Nova (Venezia: Nicolo d'Aristotile detto Zoppino, 1531).

Baldassare Castiglione, The Book of the Courtier, trans. by Leonard Eckstein Opdycke (New York: Scribners, 1903).

Die Blume des Kampfes, c.1420 (Wien, Österrische Nationalbibliothek, Cod.5278).

Fiore dei Liberi, Fior di Battaglia, c. 1409 (Los Angeles, J Paul Getty Museum, MS Ludwig XV 13).

Hans Talhoffer, 1459 (København, Det Kongelige Bibliotek, MS Thott.290.2).

Hans Talhoffer, 1467 (München, Bayerische Staatsbibliothek, Cod.icon.394a).

Joachim Meyer, Gründtliche Beschreibung der Kunst des Fechtens (Strasbourg: Thiebolt Berger, 1570).

Nürnberg, Germanisches Nationalmuseum, Cod. Hs. 3227a, c.1389.

Paris, Bibliothèque nationale de France, MS Français 1996.

Paulus Kal, c.1470 (München, Bayerisches Staatsbibliothek, Cgm 1507).

Peter Falkner, c. 1495, Kunste ₹u ritterlicher were (Wien, Kunsthistorisches Museum, MS KK5012).

Pietro Monte, Petri Montii exercitorum atque artis militaris collectanea in tris libros distincta (Milano: Giovani Angelo Scinzenzlar, 1509), online $<$ https://mazarinum.bibliotheque-mazarine.fr/records/item/2503-petri-montiiexercitiorum-atque-artis-militaris-collectanea-in-tris-libros-distincta $>$ (accessed 28/06/2019).

Pietro Monte, Pietro Monte's Collectanea: The Arms, Armour and Fighting Techniques of a Fifteenth-Century Soldier, trans. by Jeffrey L. Forgeng, (Woodbridge: Boydell, 2018).

Pietro Monte, The Collection of Renaissance Military Arts and Exercises of Pietro Monte: $A$ Translation of the Exercitorum Atque Artis Militaris Collectanea, trans. by Mike Prendergast and Ingrid Sperber, accessed online < http:/www.mikeprendergast.ie/monte/ > (accessed 27/06/19).

\section{VII.2. Secondary sources}

Anglo, Sydney, 'Le Jeu de la Hache: A Fifteenth-Century Treatise on Chivalric Axe Combat', Archaeologia, 109 (1991), 113-28.

Anglo, Sydney, 'The Man who Taught Leonardo Darts: Pietro Monte and His Lost Fencing Book', The Antiquaries Journal, 69 (1989), 261-78.

Anglo, Sydney, The Martial Arts of Renaissance Europe (New Haven and London: Yale University Press, 2000).

Briganti, Giuliano, La maniera italiana (Roma: Editori Riuniti, 1961). 
Briost, Pascal, 'Contextualising Pietro Monte's Military Career in Italy', Acta Periodica Duellatorum, 7th ser., 1 (2019), 217 - 227.

Burkart, Eric, 'Body Techniques of Combat: The Depiction of a Personal Fighting System in the Fight Books of Hans 'Talhofer (1443-1467 CE)', in Killing and Being Killed: Bodies in Battle. Perspectives on Fighters in the Middle Ages, ed. by Jörg Rogge, (Bielefeld: Transcript Verlag, 2017), pp. 109-30.

Burkart, Eric, 'The Autograph of an Erudite Martial Artist: A Close Reading of Nuremberg, Germanisches Nationalmuseum Hs. 3227a', in Late Medieval and Early Modern Fight Books: Transmission and Tradition of Martial Arts in Europe (14th - 17th Centuries), ed. by Daniel Jaquet, Karin Verelst, and Timothy Dawson (Leiden: Brill, 2016), pp. 451-80.

Deacon, Jacob Henry, 'Prologues, Poetry, Prose and Portrayals: The Purposes of Fifteenth-Century Fight Books According to the Diplomatic Evidence', Acta Periodica Duellatorum, 4th ser., 2 (2016), 69-90.

Deacon, Jacob Henry, 'The Pollaxe c. 1350 - 1550' (unpublished master's dissertation, Cardiff University, 2016).

DeVries, Kelly, Infantry Warfare in the Early Fourteenth Century: Discipline, Tactics, and Technology (Woodbridge: Boydell, 2000).

Dupuis, Olivier, and Vincent Deluz, 'Le Jeu de la Hache: A Critical Edition and Dating Discussion', Acta Periodica Duellatorum, 5th ser., 1 (2017), 3-62.

Dürer, Albrecht, Woodcuts and Wood Blocks, ed. by Walter L. Strauss (New York: Abaris Books, 1980).

Ellehauge, Martin, Certain Phases in the Origin and Development of the Glaive (København: Norlundes Bogtrykkeri, 1945).

Fontaine, Marie-Madeleine, Le Condottiere Pietro del Monte: Philosophe et Écrivain de la Renaissance, 1457-1509 (Geneve: Editions Slatkine, 1991).

Forgeng, Jeffrey L., 'Owning the Art: The German Fechtbuch Tradition', in The Noble Art of the Sword: Fashion and Fencing in Renaissance Europe, ed. by Tobias Capwell (London: Paul Holberton, 2012), pp. 164-75.

France, John (ed.), Mercenaries and Paid Men: The Mercenary Identity in the Middle Ages: Proceedings of a Conference Held at University of Wales, Swansea, 7th-9th July 2005 (Leiden: Brill, 2008).

Gombrich, Ernst Hans, The Story of Art (London: Phaidon Press, 1995).

Gradmann, Erwin, Urs Graf (Basle: Holbein Publishing Co., 1942).

Hale, John R., Artists and Warfare in the Renaissance (New Haven: Yale University Press, 1990).

Hale, John R., War and Society in Renaissance Europe, 1450-1620 (Montreal: McGillQueen's University Press, 1998).

Hall, Bert, Weapons and Warfare in Renaissance Europe: Gunpowder, Technology, and Tactics (Baltimore: Johns Hopkins University Press, 1997). 
Malipiero, Massimo, Il Fior di battaglia di Fiore dei Liberi da Cividale (Campofòrmido: Ribis, 2006).

Mallet, Michael Edward, and Christine Shaw, The Italian Wars, 1494-1559: War, State and Society in Early Modern Europe (Harlow: Pearson, 2012).

Mondschein, Ken, 'The Italian Schools of Fencing: Art, Science, and Pedagogy', in Late Medieval and Early Modern Fight Books: Transmission and Tradition of Martial Arts in Europe (14th - 17th Centuries), ed. by Daniel Jaquet, Karin Verelst, and Timothy Dawson (Leiden: Brill, 2016), pp. 280-324.

Shwetje, Burkhard, and Flavio Febbraro, How to Read World History in Art: From the Code of Hammurabit to September 11 (London: Thames and Hudson, 2010).

Stone, George Cameron, A Glossary of Construction, Decoration and Use of Arms and Armor in All Times Together With Some Closely Related Subjects (New York: Jack Brussel, 1961).

Tallett, Frank, and David J. B. Trim (eds.), European Warfare, 1350-1750

(Cambridge: Cambridge University Press, 2015).

Troso, Mario, Le armi in asta: Delle fanterie europe (Novara: Instituto Geografico De Agostini, 1988).

Tzouriadis, Iason-Eleftherios, 'The Typology and Use of Staff Weapons in Western Europe c. 1400 - c. 1550' (unpublished PhD thesis, University of Leeds, 2017).

Waldman, John Hafted Weapons in Medieval and Renaissance Europe: The Evolution of European Staff Weapons Between 1200 and 1650 (Leiden: Brill, 2005). 